\title{
Anticompetitive Patent Settlements and the Supreme Court's Actavis Decision
}

\section{Herbert Hovenkamp*}

\section{INTRODUCTION}

In FTC v. Actavis, Inc., the Supreme Court held that the settlement of a patent infringement suit in which the patentee of a branded pharmaceutical drug paid a large sum to a generic infringer to stay out of the market could be illegal under the antitrust laws. ${ }^{1}$ Further, courts assessing the antitrust illegality of such agreements need not evaluate the patent's validity or infringement. ${ }^{2}$ Such settlements must be evaluated under antitrust's rule of reason, although application need not require proof of everything that the long form rule of reason traditionally demands. ${ }^{3}$

One surprising thing about Justice Breyer's majority opinion is its unexpected generality, in two important ways. First, in addressing the "basic question," Justice Breyer opened his opinion with a story that had nothing explicitly to do with pharmaceuticals, generic drugs, or the Hatch-Waxman Act that has provoked numerous pay-for-delay settlements. Rather, it is about Company A, who sues Company B for patent infringement. Then they settle under terms in which Company $\mathrm{B}$, the defendant, agrees "not to produce the patented product until the patent's term expires," and the patentee pays Company B "many millions of dollars." 4 The Court characterized the Eleventh Circuit's decision, which the Supreme Court reversed, as nothing more than a "particular

\footnotetext{
(C) 2014 Herbert Hovenkamp

* Ben V. \& Dorothy Willie Professor of Law and History, University of Iowa. Thanks to Professor C. Scott Hemphill for commenting on a draft.

1. FTC v. Actavis, Inc., 133 S. Ct. 2223, 2229 (2013).

2. Id. at 2230-31.

3. Id. at $2237-38$.

4. Id. at 2227 .
} 
reverse payment settlement."5 The Court later acknowledged that "[a]pparently most if not all reverse payment settlement agreements arise in the context of pharmaceutical drug regulation."6 As noted below, this produced a sharp disagreement with the dissent. ${ }^{7}$ The significance of this level of generality should not be lost. The Court's subsequent analysis giving antitrust a much stronger voice in evaluating the legality of patent settlements can apply to many of them, both inside and outside the Hatch-Waxman context.

Second, Justice Breyer's opinion took a very general route in assessing the antitrust legality of pay-for-delay settlements, and one which refused to subordinate antitrust concerns to those of patent law, at least in areas where the Patent Act did not explicitly authorize the conduct in question. The obvious alternatives open to the Court were:

1. Any settlement, including one that involves pay-fordelay, is immune from antitrust attack if it is facially "within the scope of the patent." 8 For example, if a patent has six years remaining and the pay-for-delay exclusion agreement runs only five years, then the payment is lawful because the patent standing alone, if valid, would have kept the infringer out of the market in any event. Under this approach the court may not second guess the settlement by inquiring into the validity of the patent or the defendant's actual infringement; the settlement itself shields these queries from the court, with a possible exception for egregious situations involving obviously invalid patents. That is, it creates an "almost unrebuttable presumption of patent validity," and thus "assumes away the question being litigated in the underlying patent suit...."9 This is the approach that many lower courts have taken,

5. Id. (discussing the Eleventh Circuit's decision in FTC $v$. Watson Pharmaceuticals, Inc., 677 F.3d 1298, 1312 (11th Cir. 2012), rev'd sub nom. FTC v. Actavis, Inc., 133 S. Ct. 2223 (2013)).

6. Id. at 2227 (citing 12 HERBERT HOVENKAMP, ANTITRUST LAW 2046 , at 338 (3d ed. 2012); Herbert Hovenkamp, Sensible Antitrust Rules for Pharmaceutical Competition, 39 U.S.F. L. REV. 11, 24 (2004) (additional citations omitted)).

7. See infra text accompanying notes $43-58$.

8. See Actavis, 133 S. Ct. at 2239 (Roberts, C.J., dissenting) ("If [a patent holder's] actions are within the scope of the patent, they are not subject to antitrust scrutiny ....").

9. In re K-Dur Antitrust Litig., 686 F.3d 197, 214 (3d Cir. 2012) (rejecting the "scope of the patent" approach). 
including the Eleventh Circuit decision that the Supreme Court reversed, and it is consistent with a long tradition of federal judicial deference to settlements of patent infringement disputes. ${ }^{10}$ Justice Breyer acknowledged a "general legal policy favoring the settlement of disputes."11

2. A settlement payment that seems very large in proportion to anticipated litigation costs is a sign that something is wrong with the patent. It is likely either invalid or not infringed. This should be construed as an invitation to open the question that courts traditionally avoid in challenges to settlements. They should look more closely at the underlying patent and the infringement action in order to determine whether the settlement is really a good faith attempt to manage litigation and business risk, given the general uncertainty of patent infringement lawsuit outcomes. Or is this simply an attempt to continue an unjustified stream of monopoly profits, albeit with two firms sharing it rather than one? Possibilities for this close look have included direct judicial evaluation of the patent or perhaps a call for reexamination by the United States Patent and Trademark Office (USPTO). ${ }^{12}$

3. A large settlement exclusion payment disproportionate to litigation risk can be unlawful under antitrust's rule of reason, without inquiry into whether the patent is actually invalid or not infringed, and even if the settlement agreement does not go "beyond the scope" of the patent's nominal

10. FTC $v$. Watson, 677 F.3d at 1312 ("[A] reverse payment settlement is immune from antitrust attack so long as its anticompetitive effects fall within the scope of the exclusionary potential of the patent."); see also In re Ciprofloxacin Hydrochloride Antitrust Litig., 544 F.3d 1323, 1332-37 (Fed. Cir. 2008); In re Tamoxifen Citrate Antitrust Litig., 466 F.3d 187, 212-13 (2d Cir. 2006); Valley Drug Co. v. Geneva Pharm., Inc., 344 F.3d 1294, 1304, 1308 (11th Cir. 2003). On judicial deference to patent settlements, see generally 12 HovenKAMP, supra note 6, 9 2046. On the course taken by earlier decisions, see 1 HERBERT HOVENKAMP, MARK D. JANIS, MARK A. LEMLEY \& CHRIsTOPHER R. LESLIE, IP AND ANTITRUst: AN ANALYSIS OF ANTITRUsT PRINCiPles APPliEd to InTEllectual Property LAW $§ 15.3 \mathrm{a} 1(\mathrm{~B})$ (2d ed. Supp. 2012).

11. Actavis, $133 \mathrm{~S}$. Ct. at 2234 (citing several decisions).

12. See CHRISTINA BOHANNAN \& HERBERT HOVENKAMP, CREATION Without REstraint: PROMOTING LIBERTy AND RIVALRY IN INNOVATION 93-96 (2012); Gregory Dolin, Reverse Settlements as Patent Invalidity Signals, 24 HARV. J.L. \& TECH. 281, 324-26 (2011). 
coverage. The plaintiff has the burden of showing both market power and competitive harm.

4. Same as 3, except a large payment triggers a "quick look," or truncated antitrust analysis in which the plaintiff can enjoy presumptions about market power or anticompetitive effect. The defendant has the burden of defending against these and showing offsetting defenses.

5. Pay-for-delay settlements are unlawful per se-that is, the plaintiff need prove only that such an agreement exists; power and anticompetitive effects need not be proven.

The Supreme Court chose the middle option, 3, but it made clear that the plaintiff need not make a full scale rule of reason showing, which traditionally requires definition of a relevant market, detailed proof of market power, and specific anticompetitive effects. ${ }^{13}$

Stripped of nonessential regulatory detail, the pay-fordelay issue looks like this: The Hatch-Waxman Act ${ }^{14}$ was intended to streamline the introduction of "bioequivalent" generic drugs upon expiration of a patent held by the pioneer drug developer. ${ }^{15}$ "Bioequivalent" means that the generic drug has the same active ingredients as the pioneer and can be expected to perform in the same way. As a result, it is subject to much less testing than the Food and Drug Administration (FDA) requires for new drugs. ${ }^{16}$ The Act permits a generic manufacturer who believes that a pioneer drug is about to go off patent or that existing patents are invalid to file an Abbreviated New Drug Application (ANDA) seeking approval for its generic alternative. ${ }^{17}$ At that time, if the pioneer believes otherwise, it may file a patent infringement lawsuit against the generic. ${ }^{18}$ The FDA must then withhold approval pending

13. Actavis, 133 S. Ct. at 2237-38.

14. Drug Price Competition and Patent Term Restoration (HatchWaxman) Act of 1984, Pub. L. No. 98-417, 98 Stat. 1585 (codified as amended in scattered sections of $15,21,28$, and 35 U.S.C.).

15. Actavis, 133 S. Ct. at 2228 ("The Hatch-Waxman process, by allowing the generic to piggy-back on the pioneer's approval efforts, 'speed[s] the introduction of low-cost generic drugs to market' ...." (quoting Caraco Pharm. Labs., Ltd. v. Novo Nordisk A/S, 132 S. Ct. 1670, 1676 (2012))).

16. See id.; Caraco, 132 S. Ct. at 1676.

17. 21 U.S.C. $\S 355(j)(2012)$.

18. See, e.g., C. Scott Hemphill \& Mark A. Lemley, Earning Exclusivity: Generic Drug Incentives and the Hatch-Waxman Act, 77 ANTITRUST L.J. 947, $952(2011)$. 
litigation of up to thirty months until the patent dispute is resolved or settled. ${ }^{19}$ Once the generic wins the right to produce and begins marketing, it has a 180-day period of exclusivity during which no other generic may enter the market. ${ }^{20}$ During that time the market is a duopoly, with only the pioneer and the first generic as producers. However, a pay-for-delay settlement will delay the generic's commercial entry, and thus the running of the exclusivity clock, for the duration of the settlement agreement. ${ }^{21}$

Another significant thing about the Court's decision is that, notwithstanding sharp differences on the issue before it, the Court unanimously agreed that "consumer welfare" rather than total welfare is the goal of antitrust enforcement.22 In general, consumer welfare looks at the welfare only of consumers, refusing to offset producer benefits against consumer harms. By contrast, total welfare looks at all welfare effects and nets them out. For example, if a practice harms consumers $\$ 3$ million by higher prices but benefits producers by $\$ 4$ million, perhaps by lowering production costs, then total welfare is larger even though consumers are worse off. The majority's opinion was driven by a framework that equated harm with higher consumer prices, saying nothing about the welfare of producers. However, even Chief Justice Roberts' dissent (joined by Justices Scalia and Thomas) acknowledged consumer welfare to be the goal: "The point of antitrust law is

19. Chief Justice Roberts' dissent observed that the parties in this case had litigated three years before reaching their pay-for-delay settlement agreement. See Actavis, 133 S. Ct. at 2238 (Roberts, C.J., dissenting). Because the statute does not permit another generic to enter until litigation has run for thirty months, however, there is little incentive for the parties to reach an agreement earlier than that.

20. 21 U.S.C. $\S 355(\mathrm{j})(5)(\mathrm{B})(\mathrm{iv})$.

21. The process is described briefly in Justice Breyer's opinion. Actavis, 133 S. Ct. at 2228. For more detail and analysis, see 12 HovENKAMP, supra note 6, I 2046c, at 340-41; Hemphill \& Lemley, supra note 18, at 956-58; C. Scott Hemphill, Paying for Delay: Pharmaceutical Patent Settlement as a Regulatory Design Problem, 81 N.Y.U. L. REV. 1553, 1583-86 (2006) (describing the "statutory bounty" distinguishing first generic filers from subsequent challengers); Herbert Hovenkamp, Mark Janis \& Mark A. Lemley, Anticompetitive Settlement of Intellectual Property Disputes, 87 MinN. L. REV. 1719, 1754-56 (2003).

22. Actavis, 133 S. Ct. at 2234-35 (analyzing the consumer benefit provided by patent settlements); $i d$. at 2238 (Roberts, C.J., dissenting). 
to encourage competitive markets to promote consumer welfare."23

\section{IMPACT OF PAY-FOR-DELAY SETTLEMENTS ON DRUG PRICES}

A pay-for-delay settlement preserves the exclusive right created by the patent but requires the patentee to share the profits with the first generic filer. Under well-established principles, the joint-maximizing rate of output and price for this two-person cartel will be precisely the same as if the monopoly were held by a single person; ${ }^{24}$ however, the size of the payment to the generic is an indeterminate rent. The arrangement is thus similar to a situation in which two firms cartelize their market but one of them shuts down its plant altogether while the other compensates it out of its monopoly profits. Formally, consumer welfare remains the same as it would be under continued monopoly production by a single firm. Justice Breyer cited opinions to the effect that payments to generic challengers to stay out often lead to generic profits that are even higher than they would make if they had litigated to a favorable result and started producing. ${ }^{25}$ That is necessarily the case if one takes litigation risk to the generic into account. That is, a generic would not accept such a settlement unless its expected value was at least as great as the expected value of production.

Pioneer drug prices may actually rise after a large reverse payment settlement, depending on how the payment is structured. A lump sum payment made up front is a sunk cost. According to the standard economic literature, sunk costs have no impact on price. ${ }^{26}$ They are fixed costs, irreversible and made in the past. ${ }^{27}$ By contrast, prices are determined by reasonably anticipated marginal costs, which are a function of

23. Actavis, 133 S. Ct. at 2238 (Roberts, C.J., dissenting).

24. See, e.g., Herbert Hovenkamp, Federal Antitrust Policy: The LAW OF COMPETITION AND ITS PRACTICE $§ \S ~ 4.1-4.2$, at 158-78 (4th ed. 2011).

25. Actavis, 133 S. Ct. at 2235 (citing Hemphill, Paying for Delay, supra note 21, at 1581); see Carl Shapiro, Antitrust Limits to Patent Settlements, 34 RAND J. ECON. 391, 408 (2003).

26. See, e.g., Luke M. Froeb et AL., Managerial Economics 26 (3d ed. 2014) ("Because [sunk] costs do not vary with decisions about changing output, they should be ignored in decisions about output changes.").

27. See id. 
variable costs. ${ }^{28}$ The empirical literature largely disagrees, however, finding that most firms account for sunk costs in ways that include them in variable costs, and thus makes them relevant to pricing. ${ }^{29}$ In any event, to the extent that the pioneer amortizes overhead, or if the pay-for-delay settlement has some variable cost characteristics (such as varying with sales volume), then the settlement might actually be calculated into the pioneer's short-run costs and serve to increase its profit-maximizing price for the drug. Because the demand curve facing the pioneer is downward sloping, its price will rise as these costs rise. That result would be truly perverse, given the purpose of the Hatch-Waxman legislation, but price increases are clearly a possibility in some situations.

In contrast, if the patent is declared invalid and generic entry occurs, two things will happen. First, the market will have two independent producers. Second, the period of exclusivity will be no longer than the 180 days following the generic's market entry, after which additional generics can come in as well.

How the market reacts to actual generic entry depends on how the two firms behave. At one extreme, they might enter into a cartel agreement, leaving price and output as they were prior to entry. However, this agreement could not hide behind a patent settlement and would be naked price-fixing, perhaps even a criminal offense. At the other extreme, the generic might immediately begin charging a competitive price, which could be much lower than the pioneer's price, given its lower development costs. In an undifferentiated market the pioneer would have to respond with price cuts as well and the market could move quickly to the competitive level.

In fact, pioneers do not always cut price in response to generic entry and in some cases even increase it, finding it more profitable to serve a small group of brand-sensitive customers at a higher price. ${ }^{30}$ That is to say, notwithstanding

28. See, e.g., id. at $62-63$.

29. See Nabil I. Al-Najjar, Sandeep Baliga \& David Besanko, The Sunk Cost Bias and Managerial Pricing Practices (Oct. 25, 2005) (unpublished manuscript), available at http://papers.ssrn.com/sol3/papers.cfm?abstract_ $\mathrm{id}=825986$ (summarizing and accounting for the literature).

30. FTC, GENERIC DRUG ENTRY PRIOR to PATENT EXPIRATION: AN FTC STUDY 9 (2002) [hereinafter FTC STUDY], available at www.ftc.gov/os/2002/07/ genericdrugstudy.pdf. 
that generics are bioequivalent, post-entry markets sometimes reveal characteristics of product differentiation, namely, specific consumer brand preferences and differential pricing. To the extent that the Affordable Care Act, Medicare, or some other intermediary creates additional incentives for generic use, these effects may be mitigated.

In intermediate cases the two firms might reach a tacit understanding about output or behave in other ways consistent with their position as duopolists, as well as their expectations about additional entry when the exclusivity period has expired. In these cases prices would very likely begin to come down, but how much and how quickly would depend on the circumstances. ${ }^{31}$ In general, retail prices for generic drugs run about $75 \%$ lower than for branded drugs. ${ }^{32}$

\section{SIZE OF PAYMENT AND RISK}

The size of the payment for delay can be relevant in several ways. First, it signals the degree of doubt about the underlying patent dispute. To illustrate, a landowner with a clear title does not ordinarily pay a trespasser large amounts of money to stay off her property. This has nothing to do with the number of alternative trespassers out there, but results from the fact that land title records are good, generally reliable, and thus expose the landowner to minimal risk. A very large payment from the landowner to the trespasser to stay off the land is thus an irrational act unless it reflects significant doubts about the quality of the title.

While patents also confer "title" over their exclusionary power, clarity is more elusive. First, although patents on pioneer molecules, the "active" ingredient in most drugs, are among the most robust in the patent system, most of the questionable pay-for-delay settlements do not involve pioneer molecules. Rather, they are "evergreened" or extension patents for such secondary properties as new formulations, new

31. See Einer Elhauge \& Alex Krueger, Solving the Patent Settlement Puzzle, 91 TEX. L. REV. 283, 316 (2012) (concluding that a single generic entrant prices at $70 \%-88 \%$ of the pioneer's pre-entry price).

32. Cong. Budget OfFice, EFFECTs OF Using Generic DRUgS ON MEDiCARE'S PRESCRIPTION DRUG SPENDING 8-9 (2010), available at http://cbo.gov/sites/default/files/cbofiles/ftpdocs/118xx/doc11838/09-15-

prescriptiondrugs.pdf. 
delivery mechanisms, new types of treatment, and the like. ${ }^{33}$ That is, the patent is on something other than the primary active ingredient. The failure rate of these patents is much higher, and when generic challenges are litigated to completion the generic prevails more than two-thirds of the time. ${ }^{34}$ Most of the generic challenges are made to these secondary ingredient patents. ${ }^{35}$ The Solvay Pharmaceutical patent for Androgel, at issue in this case, is a likely illustration. The active ingredient, synthetic testosterone, had been around since 1935, and the gel delivery system that it incorporated had been commonly known for decades. ${ }^{36}$

Payments whose size correlates with risk are essential to entrepreneurial decision making. As risk increases the relative size of the payoff must rise as well, or investment will not occur. In most cases, however, entrepreneurial risk is private, in the sense that the firm is risking the resources of its own shareholders. In the Hatch-Waxman pay-for-delay setting, however, what is being placed at risk is both the investment of the pioneer and the welfare of consumers, and these two interests pull in opposite directions. As the plaintiff's chances of winning its infringement case drops, from say $80 \%$ to $20 \%$, the plaintiff will be willing to pay much more to protect its asset. But consumers represent an important externality. They are not participants in this dispute, but they stand to lose the benefits of competition that would otherwise have occurred. The principal risk element in pay-for-delay cases is that the

33. See, e.g., Rebecca S. Eisenberg, The Role of the FDA in Innovation Policy, 13 Mich. TELeComm. \& TECH. L. Rev. 345, 354 (2007).

34. See C. Scott Hemphill \& Bhaven Sampat, Drug Patents at the Supreme Court, 339 SCIENCE 1386, 1387 (Mar. 22, 2013); FTC STUDY, supra note 30 , at 16 (finding that generic applicants prevailed $73 \%$ of the time); see also Caraco Pharm. Labs., Ltd. v. Novo Nordisk A/S, 132 S. Ct. 1670, 1673 (2012) (permitting generics to challenge overly broad "use codes" that limited the applications of designated drugs). This compares to a general invalidity rate in the $40 \%-50 \%$ range for litigated patents. John R. Allison \& Mark A. Lemley, Empirical Evidence on the Validity of Litigated Patents, 26 AIPLA Q.J. 185, 194, 205-06 (1998).

35. See C. Scott Hemphill \& Bhaven N. Sampat, Evergreening, Patent Challenges, and Effective Market Life in Pharmaceuticals, 31 J. HEALTH ECON. 327, 334 (2012); C. Scott Hemphill \& Bhaven N. Sampat, When Do Generics Challenge Drug Patents?, 8 J. EMPIRICAL LeGal STUD. 613, 621 (2011).

36. See Second Amended Complaint for Injunctive and Other Equitable Relief 1 31, FTC v. Watson Pharm., Inc., No. 1:09-CV-00955-TWT (N.D. Ga. May 28, 2009). 
patent will be declared invalid. So the more questionable the patent-and thus the greater the likelihood that consumer benefits will be lost - the more the pioneer will be willing to pay to save it from challenge. As a result, the pay-for-delay settlement takes a patent whose probability of validity is relatively small, perhaps $35 \%$ or less, and turns it into a patent whose effective probability becomes close to $100 \%$ for the duration of the pay-for-delay settlement. This occurs by virtue of the fact that during this period no third potential producer may challenge the patent. ${ }^{37}$

Ironically, if the value of the patent were zero, because it is clearly invalid, but courts were not able to examine it, then the profit-maximizing solution for the pioneer and the first generic would still be a pay-for-delay settlement, just as if the patent were of higher quality. The size of the payment would vary inversely with the patent's perceived quality. One of the great unanticipated problems with the Hatch-Waxman procedure is that during the exclusivity period, the number of effective challengers to the patent is reduced to one, and the settlement effectively removes that one from the picture. ${ }^{38}$

In sum, the likelihood of a pay-for-delay settlement is not driven by the likelihood that the patent will be found invalid, although the size of the settlement will be. The generic's calculus depends on the size of anticipated profits under entry as opposed to the value of the settlement. Even if the generic believes there is a $100 \%$ likelihood that the patent will be found invalid, it may still be more valuable for the generic to share the monopoly returns with the pioneer patentee for the duration of the settlement agreement, rather than produce in competition with the pioneer. At the other extreme, the patentee who believes the patent is certainly valid and

37. See infra note 38 and accompanying text.

38. The exclusive period runs from the time the generic's ANDA is filed until thirty months after the patent infringement lawsuit is filed, or 180 days after generic production. See 21 U.S.C. § 355(j)(B)(iii)-(iv) (2012). Unlike European Union (EU) law, the United States does not permit anyone to challenge a patent; that right is limited mainly to those charged with infringement or facing a realistic threat of an infringement claim. In this case the Hatch-Waxman Act, by its own terms, prevents everyone except the ANDA filer from infringing. On the European procedure, see Guidelines for Examination, Part D-Guidelines for Opposition and Limitation/Revocation Procedures, EUR. PAT. OFF., http://www.epo.org/law-practice/legal-texts/ html/guidelines/e/d.htm (last updated Sept. 16, 2013). 
infringed may be willing to pay little more than a nuisance fee to avoid litigation costs, but any amount of uncertainty would likely provoke at least a modest settlement.

In sum, the Hatch-Waxman litigation process invites the parties to privatize and share a stream of monopoly profits whose aggregate value does not depend on the validity of the patent. The exclusivity period conferred by the statute sees to that by preventing other generics from coming in even if the patent is worthless. For example, if the patent confers an exclusionary right worth $\$ 800$ million over its remaining life, the pioneer and the first generic can share that amount with a suitably structured settlement, and the prohibition on outside challenges will leave that number unaffected by the value of the patent itself, which is effectively immune to challenge.

The one possible exception is a direct consumer action attacking the settlement agreement. 39 While the Supreme Court did not explore such actions, its substantial revision of the substantive law applies equally to private actions and it is reasonable to expect that several will emerge. The $K$-Dur decision in the Third Circuit permitted an action by direct purchasing consumers. ${ }^{40}$ Following Actavis, the Supreme Court vacated that decision insofar as it applied a "quick look" to the restraint, but it did not address any limitations on private plaintiff standing. ${ }^{41}$ Under Actavis, purchasers seeking antitrust overcharge damages from an anticompetitive pay-fordelay settlement should be able to proceed without proving patent invalidity, although they would be subject to the same rule of reason constraints that the Court created for the FTC.

\section{UBIQUITY OF PAY-FOR DELAY SETTLEMENTS}

One important debate between the Actavis majority and dissent concerned the ubiquity of pay-for-delay settlements. Are such settlements a unique feature of the Hatch-Waxman

39. Cf. Ritz Camera \& Image, LLC v. SanDisk Corp., 700 F.3d 503, 508 (Fed. Cir. 2012) (permitting consumers to challenge allegedly unlawful patent exclusion under antitrust laws).

40. In re K-Dur Antitrust Litig., 686 F.3d 197 (3d Cir. 2012), vacated sub nom. Merck \& Co., Inc. v. La. Wholesale Drug Co., 133 S. Ct. 2849 (2013); see also In re DDAVP Direct Purchaser Antitrust Litig., 585 F.3d 677, 691-92 (2d Cir. 2009) (permitting a consumer challenge to an agreement between pioneer and generic that allegedly inflated the price of the generic drug).

41. See Merck \& Co., 133 S. Ct. at 2849. 
regime, suggesting that they are not particularly important to the efficient functioning of the patent litigation system generally? Or are they quite common in the general give-andtake of patent litigation settlements, although perhaps not particularly well publicized? The question is hardly trivial, given the majority's conclusion that pay-for-delay patent settlements can restrain trade and thus violate the antitrust laws even if the patent is valid. The premise is that there are better, less anticompetitive ways to settle these disputes, including production licenses to the generic, and rule of reason analysis includes a query into the availability of less restrictive alternatives. ${ }^{42}$

Chief Justice Roberts' dissent took issue with the majority's conclusion that pay-for-delay settlements are virtually unknown outside the Hatch-Waxman context. ${ }^{43} \mathrm{He}$ cited a law review article and the Respondent's brief, which had mentioned a few cases. ${ }^{44}$ The Chief Justice then suggested that there might be "scores and scores" of such settlements, but they are not well known because they are private agreements. ${ }^{45}$

None of the three cases that the respondents uncovered involved patents. The $M G M$ decision involved a trademark dispute over the defendant's use of "007" as a company and product name, which Metro claimed was owned by its affiliates as part of its James Bond 007 marks. ${ }^{46}$ The district court refused to issue a preliminary injunction, and the parties then settled under an arrangement in which Metro paid the infringement defendant $\$ 150,000.47$ In exchange the defendant was permitted to continue to use "007" in its company name, but not on specific products. ${ }^{48}$ The $\$ 150,000$ was almost certainly within litigation risks, particularly since the district

42. On the relevance of less restrictive alternatives to rule of reason analysis, see 7 PHILliP E. AREEDA \& HERBERT HOVENKAMP, ANTITRUST LAW ๆ 1505b, at 417-19 (3d ed. 2010).

43. See Actavis, 133 S. Ct. at 2235 (citing 1 HovenKAMP, JANIS, LEMLEY \& LESLIE, supra note 10, § 15.3, at 15-45 n.161 (2d ed. Supp. 2011)).

44. See id. at 2243 (Roberts, C.J., dissenting) (discussing Marc G. Schildkraut, Patent-Splitting Settlements and the Reverse Payment Fallacy, 71 ANTITRUsT L.J. 1033, 1046 (2004)).

45. Id.

46. Metro-Goldwyn Mayer, Inc. v. 007 Safety Prods., Inc., 183 F.3d 10 (1st Cir. 1999).

47. Id. at 13 .

48. Id. 
Court had denied a preliminary injunction. 49 In In Time Products, the district court had also denied a preliminary injunction on the plaintiff's claims for copyright and trade dress infringement committed by the defendant's robot toys. ${ }^{50}$ At that point the plaintiff agreed to purchase the defendant's allegedly infringing inventory for an amount of less than $\$ 200,000$, plus an additional $\$ 150,000$ for the destruction of other inventory. ${ }^{51}$ Once again, these amounts seem to be within litigation risks, and are practically trivial when compared with the multihundred-million dollar figures involved in some pay-for-delay pharmaceutical patent settlements.

The only dispute cited by the respondents that produced a larger settlement, $\$ 20$ million, was between Microsoft and Lindows.com, a company which made an open source Linuxbased operating system for computers with Windows architecture.52 Microsoft alleged that "Lindows" was confusingly similar to "Windows." 53 The background, which the respondents did not recite, is worth noting. Microsoft had already been denied a preliminary injunction twice, with the second decision concluding that there was a genuine issue of material fact whether the name "Windows" was generic and thus could not have trademark protection. ${ }^{54}$ At the time of the settlement the district court had already decided that the issue of genericness should be given to a jury, but it then certified that decision for interlocutory appeal. 55 Previously the USPTO had twice refused to register "Windows" as a trademark because it believed the term to be generic, but then changed its mind without explanation. ${ }^{56}$ In sum, at the time of the

49. Id.

50. In Time Prods., Ltd. v. Toy Biz, Inc., 38 F.3d 660, 662 (2d Cir. 1994).

51. Id.

52. See Douglas F. Gray, Microsoft Sues Lindows.com over Name, TECH HIVE (Dec. 21, 2001， 8:00 AM), http://www.pcworld.com/article/77163/ article.html.

53. See Brief for Respondent Actavis, Inc. at 54 n.20, FTC v. Actavis, Inc., 133 S. Ct. 2223 (2013) (No. 12-416), 2013 WL 662705, at *54 n.20; Joris Evers, Microsoft, Lindows Make a Deal, TECH HIVE (July 19, 2004, 2:00 PM), http://www.techhive.com/article/116947/article.html.

54. See Microsoft Corp. v. Lindows.com, Inc., No. C01-2115C, 2002 WL 32085605, at *3-5 (W.D. Wash. May 13, 2002).

55. See Microsoft Corp. v. Lindows.com, Inc., No. C01-2115C, 2004 WL 329250 (W.D. Wash. Feb. 10, 2004).

56. See id.; Microsoft Corp. v. Lindows.com, Inc., No. C01-2115C, 2002 WL 31499324 (W.D. Wash. Mar. 15, 2002). 
settlement Microsoft faced a serious threat that it would lose its trademark on the "Windows" name. Twenty million dollars was a small price to pay.

So, yes, there may be some reverse payment settlements outside the Hatch-Waxman context.57 Further, Chief Justice Roberts' point that there could be many pay-for-delay patent settlements out there that have not been disclosed is well taken. Nevertheless, one would think that the interest groups in this case, with significant resources and patent experience, could have come up with more examples had they been there to discover, and perhaps at least one that involved patents. Based on this record, pay-for-delay seems to be predominantly if not exclusively a feature of the Hatch-Waxman Act. ${ }^{58}$

\section{APPLYING ANTITRUST TO PAY-FOR-DELAY SETTLEMENTS}

\section{A. Pre- Vs. Post-Issuance Practices}

The patent regime is characterized by active regulatory scrutiny during the application and prosecution process, but very little scrutiny once a patent has issued. ${ }^{59}$ Well-established rules of implied antitrust immunity thus suggest that antitrust has little place as a governor of the patent issuance process, ${ }^{60}$ but considerable room remains to apply antitrust to practices

57. The term "pay-for-delay" seems inappropriate here, since the trademarks at issue in the discussed cases are of indefinite duration. These settlements were very likely "permanent," keeping the defendant out of the market indefinitely.

58. Justice Breyer appropriately rejected a suggestion he attributed to the dissent that the patentee who settles for something less than its initial demand is effectively accepting a "reverse payment" for the balance. See Actavis, 133 S. Ct. at 2233 (discussing Schildkraut, supra note 44, at 1046). Justice Breyer referenced the patentee who demands $\$ 100$ million for infringement by a producing infringer and ends up settling for $\$ 40$ million, with the suggestion that this in fact amounts to a "reverse payment" of the unpaid $\$ 60$ million. Id. In any event, in this story the alleged infringer actually produces rather than exiting from the market, and the size of the license fee is irrelevant. Indeed, in the absence of any infringement litigation whatsoever the patentee could lawfully accept any price it wished as a licensing fee from a producer.

59. BOHANNAN \& HOVENKAMP, supra note 12, at 83-85.

60. See 1A Phillip E. AREeda \& Herbert Hovenkamp, ANTItrust LaW ๆๆ 240-244 (4th ed. 2013). 
involving issued patents. ${ }^{61}$ Patents are property interests and assets, and can be made subject to antitrust rules governing mergers, ${ }^{62}$ price-fixing, ${ }^{63}$ tying, ${ }^{64}$ and other practices. Obviously, settlements of patent infringement suits are postissuance practices. The one clear exception to this rule is express immunity: if the Patent Act expressly authorizes a specific practice, then that practice standing alone cannot violate the more general antitrust laws. ${ }^{65}$

The general rule of judicial deference to settlements of patent infringement suits rests mainly on a belief that, while patents are property interests, they are plagued with validity and boundary problems so severe that judges cannot have a great deal of confidence in the courts. ${ }^{66}$ They must defer to the parties' reasonable, good faith assessments of likely outcomes and risk. Significantly, however, in most settlements the plaintiff and defendant have interests aligned against one another and the settlement contemplates a production license. As a result there is typically little reason for thinking that any nonparticipating interest group is significantly injured by the settlement and consumers typically benefit. 67 By contrast, the impact of Hatch-Waxman's generic exclusivity provision is

61. Even the Supreme Court's rule in Walker Process Equip., Inc. v. Food Mach. \& Chem. Corp., 382 U.S. 172, 177 (1965), involved, not the initial use of false statements about prior sales to obtain a patent, but rather the postissuance assertion of a patent known to be invalid in an infringement suit. See

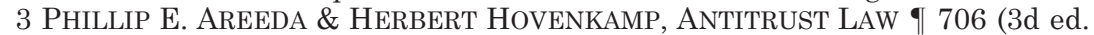
2008). Under U.S. law, simply using fraud or inequitable conduct to obtain the patent is disciplined through the Patent Act and USPTO procedures rather than antitrust. See id. I 706, at 255 ("As a general proposition, merely obtaining a patent by fraud with no subsequent enforcement attempt, is not an exclusionary practice under [antitrust law].”).

62. See 5 Phillip E. AREedA \& Herbert HovenKAmp, ANTITRUst LaW I 1202f, at 273 (3d ed. 2009) (patents are "assets" subject to antitrust merger laws).

63. United States v. Line Material Co., 333 U.S. 287, 315 (1948).

64. 15 U.S.C. $\S 14$ (2012) (prohibiting anticompetitive use of tying or exclusive dealing in goods, "whether patented or unpatented").

65. On express immunity, see 1A AREEDA \& HovENKAMP, supra note 60, I $243 \mathrm{~b}$, at $336-38$.

66. Cf. Hemphill, Paying for Delay, supra note 21, at 1574 ("[A judicial reflex in favor of settlement] may be unusually acute due to the highly technical nature of pharmaceutical patent cases, which many federal judges prefer to avoid.").

67. The exceptions are situations where the settlement also contemplates product price-fixing, market division, or some other restraint that may injure consumers. See 12 HovenKAMP, supra note 6, ๆ \ 2046b4-2046b5. 
frequently to align the interests of both plaintiff and defendant in favor of preserving exclusivity but sharing the proceeds, contrary to the interests of consumers. In these cases, the size of the settlement payment is undoubtedly a more reliable indicator of the parties' own assessment of likely litigation outcomes than is any conclusion that can be drawn from the fact of settlement itself.

As noted, outside the Hatch-Waxman context patent infringement lawsuits are very frequently settled by agreements that contemplate a license to the infringement defendant, with a payment from it to the patentee rather than vice-versa. ${ }^{68}$ Such licenses are expressly authorized by the Patent Act, whether or not they are preceded by a dispute. ${ }^{69}$ Further, they ordinarily add one new producer into the market and presumptively increase output. As a result they do not frequently raise antitrust issues. Justice Breyer noted the Supreme Court's pooling arrangement in the Standard Oil Co. (Indiana) case, which settled litigation by a broad cross-license that permitted all parties to practice, but also warned that it might not be so generous with agreements that threatened to dominate the industry and curtail production. ${ }^{70}$

The traditional antitrust challenges to patent settlements have generally been to collateral provisions, such as product price-fixing between patentees and licensees, 71 concerted refusals directed at others, ${ }^{72}$ or some market division agreements. ${ }^{73}$ While the Patent Act contemplates licensing and actual production by others, ${ }^{74}$ it nowhere justifies reverse payments to keep others out. This was relevant to Justice Breyer's query whether "'the patent statute specifically gives a

68. See, e.g., Michael J. Chapman, Using Settlement Licenses in Reasonable Royalty Determinations, 49 IDEA 313, 315-16 (2009).

69. 35 U.S.C. $§ 261$ (2006 \& Supp. V 2011).

70. FTC v. Actavis, Inc., 133 S. Ct. 2223, 2232-33 (citing Standard Oil Co. (Ind.) v. United States, 283 U.S. 163, 174 (1931)).

71. United States v. Gen. Elec. Co., 272 U.S. 476, 494 (1926) (upholding license agreement between patentee and a single producing licensee that fixed the latter's product price); E. Bement \& Sons v. Nat'l Harrow Co., 186 U.S. 70 (1902) (upholding patent pool that fixed product price).

72. United States v. Singer Mfg. Co., 374 U.S. 174 (1963).

73. E.g., Hartford-Empire Co. v. United States, 323 U.S. 386 (1945); cf. Palmer v. BRG of Ga., Inc., 498 U.S. 46 (1990) (applying per se rule to a horizontal trademark license agreement with territorial division).

74. 35 U.S.C. $\S 261$. 
right' to restrain competition in the manner challenged,"75 as well as his critique of the dissent because it did "not identify any patent statute that it understands to grant such a right [as reverse payment settlements] to a patentee, whether expressly or by fair implication."76 He also noted that nothing in the Hatch-Waxman Act could be read as approving pay-for-delay settlements, but instead strongly indicated that its goal was to increase competition by facilitating the entry of generic drugs. ${ }^{77}$

Closer antitrust scrutiny of practices that threaten competitive harm but are not expressly authorized by the Patent Act makes sense given the degree of producer influence over the drafting of patent legislation. ${ }^{78}$ At least since the passage of the 1952 Patent Act, the legislative drafting process has largely reflected the wishes of business firms who have a direct financial interest in the patent process. Consumer interests are largely ignored, even though their interests are most closely aligned with the general welfare. Consumers profit from cost-justified innovation in product quality and variety, as well as cost savings. By contrast, producer interests are much more diverse and more frequently aligned with increased protection for its own sake. ${ }^{79}$ This history has shown that producer interests opposed to a particular judicial interpretation of the Patent Act have been quite successful in obtaining changes. This was true, for example, of the 1952 Patent Act, which was a reaction to what the Patent Bar perceived as excessive Supreme Court hostility toward patents. ${ }^{80}$ It was also true of the 1988 Patent Misuse Reform

75. Actavis, 133 S. Ct. at 2231 (quoting United States v. Line Material Co., 333 U.S. 287, 310-11 (1948)).

76. Id. at 2233 .

77. Id. at 2234 .

78. See Robert P. Merges, One Hundred Years of Solicitude: Intellectual Property Law, 1900-2000, 88 CALIF. L. REV. 2187, 2200 (2000); Liza Vertinsky, Comparing Alternative Institutional Paths to Patent Reform, 61 ALA. L. REV. 501, 526 (2010) ("Indeed, the role of industry groups in influencing and even drafting intellectual property legislation has been noted ....").

79. See Herbert Hovenkamp, Consumer Welfare in Competition and Intellectual Property Law, COMPETITION POL'Y INT'L J., Autumn 2013, at 53, 61; Craig Allen Nard, Legal Forms and the Common Law of Patents, 90 B.U. L. REV. 51, 52 n.2 (2010).

80. See HERBERT HOVENKAMP, THE OPENING OF AMERICAN LAW: NeOClassical LEgal THOUght, 1870-1970, at ch. 10 (forthcoming 2014); see also Nard, supra note 79, at 72 ("The heart of the 1952 Act was a direct 
Act, which largely eliminated liability for patent tying in the absence of market power, as well as unilateral refusals to deal. ${ }^{81}$ If these interests believe that reverse payment settlements ought to have statutory approval, they are in the best position to obtain new legislation. As a result, there is much to be said for a judicial practice of looking at the challenged restraint to see if it poses a significant risk of competitive harm and then deferring to patent law only when the challenged practice is explicitly approved by the statute.

\section{B. RELEVANCE OF PATENT INVALIDITY OR NONINFRINGEMENT}

As noted above, Justice Breyer's decision contemplated that a court could invalidate a pay-for delay settlement without digging into questions about validity or infringement. 82 That conclusion will very likely be one of the more controversial parts of his opinion, but it is consistent with the FTC's long held position. Justice Breyer also noted that, very likely in this case, the settlement's "anticompetitive effects fall within the scope of the exclusionary potential of the patent." 83 However, this fact was insufficient to "immunize the agreement from antitrust attack." 84

On the question of judicial obligation to consider patent validity, the Court wrote:

[I]t is normally not necessary to litigate patent validity to answer the antitrust question.... An unexplained large reverse payment itself would normally suggest that the patentee has serious doubts about the patent's survival.... In a word, the size of the unexplained reverse payment can provide a workable surrogate for a patent's weakness, all without forcing a court to conduct a detailed exploration of the validity of the patent itself. ${ }^{85}$

Later the Court reiterated that, although it was requiring a rule of reason treatment with the burden of proof generally on the plaintiff, this did not require the FTC to "litigate the patent's validity, empirically demonstrate the virtues or vices

response to the Supreme Court's patent jurisprudence over the previous several years.").

81. 35 U.S.C. $§ 271(d)(4)-(5)$ (2006 \& Supp. V 2011); see also Christina Bohannan, IP Misuse as Foreclosure, 96 IowA L. REV. 475, 487-88 (2012).

82. Actavis, 133 S. Ct. at 2237.

83. Id. at 2230 .

84. $I d$.

85. Id. at 2236-37 (emphasis added) (citing 12 HovEnKAMP, supra note 6, I 2046, at 350-52). 
of the patent system, present every possible supporting factor or refute every possible pro-defense theory." 86 This entails that patent validity is not a separate consideration for either the plaintiff's case or the defense. Both would require litigation of the patent's validity.

In one sense, the size of the payment operates as a surrogate for direct patent-law-based questions about patent quality. Indeed, payment size may actually be a more reliable indicator to the extent it reflects the settling parties' marketbased judgment about the patent's probable prospects in a fully litigated infringement suit. Data on claim construction error rates, ${ }^{87}$ the high percentage of litigated patents found to be invalid, and high reversal rates, ${ }^{88}$ all suggest that the size of the payment may in fact be at least as good a tool for assessing patent quality as a direct look at the patent itself. This is most likely to be the case where the pay-for-delay settlement is on something other than the patent's active ingredient, as in Actavis itself. 89

Beyond that, however, patent validity does not answer the antitrust question, which is whether a settlement of a particular type restrains trade unreasonably. As the majority observed:

The owner of a particularly valuable patent might contend, of course, that even a small risk of invalidity justifies a large payment. But, be that as it may, the payment (if otherwise unexplained) likely

86. Id. at 2237-38 (quoting Cal. Dental Ass'n v. FTC, 526 U.S. 756, 780 (1999) (quoting 7 PHILLIP AREEDA \& HERBERT HOVENKAMP, ANTITRUST LAW II 1507, at 402 (1st ed. 1986))).

87. See David L. Schwartz, Practice Makes Perfect? An Empirical Study of Claim Construction Reversal Rates in Patent Cases, 107 MicH. L. REV. 223, 246 (2008) (finding district court error rates in claim construction ranging from $25 \%-50 \%$, depending on definitions used); see also J. Jonas Anderson \& Peter S. Menell, Informal Deference: An Historical, Empirical, and Normative Analysis of Patent Claim Construction, 108 NW. U. L. REV. (forthcoming 2014), available at http://papers.ssrn.com/sol3/papers.cfm?abstract_id=2150360.

88. Allison \& Lemley, supra note 34; see also Ted L. Field, "Juridical Hyperactivity" in the Federal Circuit: An Empirical Study, 46 U.S.F. L. REV. 721, 723 (2012) (finding the Federal Circuit's reversal rates to be greater than other circuits studied). On district-specific reversal rates, see Teresa Lii, Shopping for Reversals: How Accuracy Differs Across Patent Litigation Forums, 12 CHI.-KENT J. INTELL. PROP. 31, 43 (2013) (looking at many district courts and finding a weighted average reversal rate of $37.8 \%$ ).

89. See supra notes $34-36$ and accompanying text. 
seeks to prevent the risk of competition. And, as we have said, that consequence constitutes the relevant anticompetitive harm..$^{90}$

Further, it would be:

[I]ncongruous to determine antitrust legality by measuring the settlement's anticompetitive effects solely against patent law policy, rather than by measuring them against procompetitive antitrust policies as well. And indeed, contrary to the Circuit's view that the only pertinent question is whether "the settlement agreement... fall[s] within" the legitimate "scope" of the patent's "exclusionary potential," this Court has indicated that patent and antitrust policies are both relevant in determining the "scope of the patent monopoly" - and consequently antitrust law immunity—that is conferred by a patent. ${ }^{91}$

A striking part of Justice Breyer's discussion of Supreme Court precedent was its showing that restraints involving patents whose validity or coverage was not in dispute could nevertheless run afoul of the Sherman Act, even outside of the Hatch-Waxman context. ${ }^{92}$ In the process he gave the narrowest interpretation of the oft-criticized 1926 General Electric rule that the Supreme Court has ever stated, declaring that it "permitted a single patentee to grant to a single licensee a license containing a minimum resale price requirement." 93 The statement appears implicitly to overrule the Supreme Court's Bement decision, which permitted product price-fixing among the numerous members of a patent pool. ${ }^{94}$

\section{The Rule of Reason for Reverse Payment SETtlements}

Justice Breyer's majority opinion rejected the Federal Trade Commission's position in one significant respect: he declined to apply any kind of "quick look" analysis that granted the Commission a presumption of illegality. At the same time, however, the Court made clear that a "long form" rule of reason was not necessary either.

90. Actavis, 133 S. Ct. at 2236.

91. Id. at 2231 (internal citation omitted).

92. See, e.g., id. at 2231 ("[C]ourts must "balance the privileges of [the patent holder] and its licensees under the patent grants with the prohibitions of the Sherman Act against combinations and attempts to monopolize." (quoting United States v. U.S. Gypsum Co., 333 U.S. 364, 390-91 (1948))).

93. Id. at 2232 (discussing United States v. Gen. Elec. Co., 272 U.S. 476, 489 (1926)). A few lower courts had adopted this formulation. See 12 HOVENKAMP, supra note 6, ๆ 2041b.

94. E. Bement \& Sons v. Nat'l Harrow Co., 186 U.S. 70 (1902). 
In general, analysis of a contractual restraint under the rule of reason requires a showing of (1) power sufficient to warrant a conclusion of plausible competitive harm; (2) a restraint that threatens to reduce output or increase price and that (3) is not justified by efficiencies or some other redeeming virtue. ${ }^{95}$ Without departing from any of these principles, the majority's opinion in Actavis permitted trial courts to "structure antitrust litigation so as to avoid, on the one hand, the use of antitrust theories too abbreviated to permit proper analysis, and, on the other, consideration of every possible fact or theory irrespective of the minimal light it may shed . ..."96

This approach is consistent with the Supreme Court's historical reluctance to adopt any kind of bipolar distinction between a full "rule of reason" on one hand and a drastically abbreviated "quick look" on the other. Rather, the analysis is situational and requires the court to consider factors relevant to the question at hand and to create presumptions based on its estimate of likelihood of proof.97 The Court observed that "[t]here is always something of a sliding scale in appraising reasonableness," and that "the quality of proof required should vary with the circumstances." 98

The majority's reasoning reflects the view that the various modes of antitrust analysis actually manage two variables at the same time. One variable is burdens of proof and presumptions, while the other has to do with the kind of evidence needed to carry one's burden. The per se rule weighs both variables strongly in the plaintiff's favor once per se conduct is shown. The "quick look," as the FTC has formulated it, also created presumptions of power and harm in the plaintiff's favor. By contrast, what the Actavis majority stated was that the presumptions continue to lie with the defendant, thus giving the plaintiff the burden of proof. ${ }^{99}$ However, the nature of the evidence needed to carry one's burden can also vary with the circumstances. Here the Court was clear that more abbreviated proof than ordinarily attends the full rule of

95. See 7 AREEDA \& HovenKAMP, supra note 42, 1502 , at 389.

96. Actavis, 133 S. Ct. at 2238.

97. See 7 AREEDA \& HovenKAMP, supra note 42, ๆ 1507,1508 c.

98. Actavis, 133 S. Ct. at 2237-38 (quoting Cal. Dental Ass'n v. FTC, 526 U.S. 756, 780 (1999) (quoting 7 AREEDA \& HovENKAMP, supra note 86, ๆ 1507, at 402) (internal punctuation omitted)).

99. Id. at 2237 . 
reason was available for both power and anticompetitive effects.

On power, the Court suggested that the "size of the payment from a branded drug manufacturer to a prospective generic is itself a strong indicator of power."100 That observation, which should dispense with any requirement of a relevant market definition, seems beyond dispute for very large payments. In a competitive market the value of keeping a competitor out is close to zero, but becomes higher as price-cost margins increase. Further, in these cases the duration of the monopoly is not infinite, but is limited by the remaining duration of the patent. A rational patentee would pay no more than the anticipated value of monopoly returns over the remaining period, so a large payment surely indicates power. Indeed, this form of more "direct" measurement is probably as good as or better than traditional market definition approaches. 101

One complaint about using a large payment as proof of power is that it ignores the high fixed costs of pioneer product development, which may require prices above short-run marginal costs so that fixed costs can be recovered. That argument misses Justice Breyer's point, however. First, the fixed cost critique applies to one degree or another to all of our mechanisms for assessing power, including the Lerner Index and its many derivations, ${ }^{102}$ as well as even orthodox market delineation through the methodology of assuming a price increase to supracompetitive levels. ${ }^{103}$ In every case, high fixed costs tend to result in conclusions of greater market power or smaller markets, which is the same thing. Second, long-run ability to earn a profit is not the concern of antitrust market power assessment in any event. Fixed costs are one of the many risks that a firm undertakes, and they do so in a regime in which there is no defense to price-fixing, naked market division, or exclusionary practices on the theory that the practice is necessary to keep price/cost margins sufficiently

100. Id. at 2236 (quoting 12 HoVENKAMP, supra note 6, ๆ 2046, at 351).

101. See 2B PHILLIP E. AREEDA, JOHN L. SOLOW \& HERBERT HOVENKAMP, ANTITRUST LAW $\mid$ I 515, 521 (3d ed. 2007) (describing price-cost margins in I 515 and direct measures based on demand elasticities in 921 ).

102. 2B Phillip E. AREEDA \& HERBERT HovenKAMP, ANTITRUst LAW

If 520e (4th ed. forthcoming 2014).

103. Id. ๆ $536-539$. 
high to enable it to recover its investment. Even if we believed that a firm is entitled to use a collusive practice in order to obtain a margin sufficiently high to cover its fixed cost investment, this would not entail that it is entitled to recover the full monopoly profits available from that market.

This latter point should not be lost because it explains why high fixed costs do not provide a general defense to collusion, whether in the Hatch-Waxman context or elsewhere. The amount of margin a firm needs to recover its fixed costs is a function of the magnitude of those costs and of aggregate pricecost margins during the recovery period. By contrast, the monopoly price is a function of costs and market demand, and that number can be far, far higher. For example, a firm with marginal costs of eight dollars and high fixed costs may need a price of ten dollars in order to recover its fixed-cost investment. The monopoly price in that market might be fifteen dollars, depending on demand. Permitting collusion or market division without antitrust scrutiny allows the firm to earn the full monopoly markup.

The rule of reason requires not only proof of power, but also of competitive harm, of which higher consumer prices or reduced output are the clearest types. Here, the Court noted that the size of the payment was also an indicator of competitive harm.104 A large payment would be an irrational act unless the patentee believed that generic production would cut into its profits. Here, "the likelihood of a reverse payment bringing about anticompetitive effects depends upon its size, its scale in relation to the payor's anticipated future litigation costs, its independence from other services for which it might represent payment, and the lack of any other convincing justification."105

The Court also noted that sometimes the agreements could have "redeeming virtues," although the list Justice Breyer provided was not long. ${ }^{106}$ It included the observation that some settlements may constitute little more "than a rough approximation of the litigation expenses saved through the settlement."107 In other cases the payment may constitute

104. Actavis, 133 S. Ct. at 2236.

105. Id. at 2237.

106. Id. at 2236 .

107. Id. 
"compensation for other services" that the generic might perform, including distribution or market development.108 Adequate proof would be required.

Interests aligned with the drug companies were critical of the decision, suggesting that it will create uncertainty and discourage innovation. ${ }^{109}$ But that seems unlikely. First, a sensibly applied rule of reason as the Supreme Court majority outlined need not be complex, certainly not when compared to the general run of FTC antitrust cases. Very large payments shielding very weak patents from outsider scrutiny will occur much less frequently, but that is how it should be. Pharmaceutical developers will continue to have strong protection for primary patents on active ingredients, but weakened protection for secondary patents in areas where fully litigated invalidity rates are very high. Intermediate cases are more likely to be litigated to a validity decision or else settle by more traditional methods, including production licenses to generic infringement defendants or an agreement to delay entry but without any compensation to the generic.

One important feature of traditional settlements such as production licenses is that they reflect adversity between the parties. ${ }^{110}$ The patentee wants to obtain as high a production royalty as possible and the infringement defendant wants to pay as little. The same thing is generally true of agreements delaying entry but without anything of value changing hands. Suppose that the pioneer simply agrees with the generic that the generic can enter several years from now and nothing of value changes hands. In that case the generic will want to make the delay as short as possible, while the pioneer will want to make it longer, and the parties have sufficient adversity to give us some confidence that a realistic assessment of the strength of the patent is included in their calculus. By contrast, the pay-for-delay settlement permits the parties to

108. Id.

109. See, e.g., PhRMA Statement on Supreme Court Ruling in Patent Settlement Case, PHRMA (June 17, 2013), http://phrma.org/phrma-statementon-supreme-court-ruling-in-patent-settlement-case.

110. See U.S. DOJ \& FTC, ANTITRUST GUIDELINES FOR THE LICENSING OF INTELLECTUAL PROPERTY $§ 2.3$ (1996), available at http://www.justice.gov/ atr/public/guidelines/0558.pdf (speaking of procompetitive benefits of licensing); cf. Adam Hemlock \& Jennifer Wu, U.S. Antitrust Implications of Patent Licensing, 52 FED. LAW., June 2005, at 39, 40 ("Patent licensing can have significant potential benefits that promote competition."). 
share the full monopoly overcharge, giving each of them an expected value greater than the probable value of the patent in question.

\section{ADMINISTRABILITY}

The majority and the dissent stated starkly different views about administrability of an antitrust rule governing pay-fordelay patent settlements. Justice Breyer wrote for the Court that "an antitrust action is likely to prove more feasible administratively than the Eleventh Circuit believed." 111 In contrast, Chief Justice Roberts declared that he would "not subject basic questions of patent law to an unbounded inquiry under antitrust law, with its treble damages and famously burdensome discovery ...." 112

Of course, the simplest rule is no rule at all, and in that sense the Chief Justice is correct. On the other hand, the analytic approach that the majority developed is actually at the simpler range of antitrust doctrine, and certainly not as complex as a regime that would require a court to assess patent validity or weigh the impact of the settlement agreement on incentives to innovate. The pay-for-delay agreements in question are written and detailed, so proof of an agreement and its content is typically not in issue. Determining whether the agreement is unreasonably large in comparison with litigation costs should not prove burdensome either, because such data are kept and reported. The dissent cited one study indicating a number in the range of $\$ 10$ million per lawsuit, somewhat higher than the cost of patent litigation generally. ${ }^{113} \mathrm{~A}$ good approach would be to start with a presumptive number of about that size, letting the parties dispute whether special factors in their case justify a number that is higher or lower.

Determining the market value of any services actually rendered by the generic should not be complex either, given

111. Actavis, 133 S. Ct. at 2236. On how the lower courts should administer pay-for-delay antitrust challenges in the future, see Aaron Edlin, Scott Hemphill, Herbert Hovenkamp \& Carl Shapiro, Activating Actavis, ANTITRUST, Fall 2013, at 16.

112. Actavis, 133 S. Ct. at 2247 (Roberts, C.J., dissenting).

113. Id. at 2243-44 (citing Michael R. Herman, Note, The Stay Dilemma: Examining Brand and Generic Incentives for Delaying the Resolution of Pharmaceutical Patent Litigation, 111 COLUM. L. REV. 1788, 1795 n.41 (2011)); cf. 1 HOVENKAMP, JANIS, LEMLEY \& LESLIE, supra note 10, § 7.1c, at 5 n.6 (indicating $\$ 1.5$ million per side in legal fees). 
that these services are routinely sold in a broad market. The court needs to ensure mainly that the services are being priced at the reasonable market value of what is actually provided. For example, if general distributors are providing services of a certain kind for fifty cents per package, that number should serve as a benchmark for pricing of services in a settlement. The most difficult part of such cases-determining the validity of the patent-was made unnecessary by the Court's antitrustcentric approach.

\section{CONCLUSION}

The dissent suggested that a "patent carves out an exception to the applicability of antitrust laws."114 Given the high degree of federal regulatory supervision over the patent granting process, a regulatory exception for most pre-issuance conduct before the USPTO is in order. But once a patent issues it is largely an unregulated asset capable of both efficient and harmful use, just as any other business property.

The dissent also posited what appears to be a false dichotomy: "We have never held that it violates the antitrust law for a competitor to refrain from challenging a patent. And by extension, we have long recognized that the settlement of patent litigation does not by itself violate the antitrust laws." 115 Of course, unilateral failure to enter a market, whether by challenging a patent or otherwise, is virtually never an antitrust violation, while an agreement that one party will not enter clearly can be.116 The case that Chief Justice Roberts cited for the proposition that settlements do not violate the antitrust laws was Standard Oil Co. (Indiana), where the settlement involved cross-licensing and actual production by all of the parties. ${ }^{117}$

The dissent also suggested that routinely approved settlements have included "licenses that fix prices, or agreements among competitors to divide territory." 118 The

114. Actavis, 133 S. Ct. at 2238.

115. Id. at 2239 .

116. This was the principle issue in Twombly, where the fact of non-entry was clear, and antitrust liability turned on whether the non-entry was the consequence of a unilateral decision of an agreement. Bell Atlantic Corp. v. Twombly, 550 U.S. 544 (2007).

117. Standard Oil Co. (Ind.) v. United States, 283 U.S. 163, 174 (1931).

118. Actavis, 133 S. Ct. at 2239 (Roberts, C.J., dissenting). 
record is in fact more mixed. Assuming that the Chief Justice was talking about product price-fixing rather than merely an agreement about the royalty rate of a negotiated license, then price-fixing is hardly routinely approved, save for the infamous "GE exception" discussed above. 119 Territorial division agreements are usually lawful, but that is because the Patent Act contains an express provision authorizing patentees to stipulate territories in their license agreements, at least within the United States.120 The dissent's statement that "a patent holder acting within the scope of its patent does not engage in any unlawful anticompetitive behavior" 121 seems difficult to square with the routine application of section 7 of the Clayton Act to asset acquisitions of patents, ${ }^{122}$ notwithstanding that the Patent Act expressly permits assignments. ${ }^{123}$ Implicitly, then, it permits only assignments that are not found to be anticompetitive. The same thing is true of patent tying arrangements, which the Patent Act expressly shelters, but only if the patentee lacks market power; ${ }^{124}$ otherwise they are subject to routine antitrust analysis.

On pay-for-delay itself, the Supreme Court's decision was broad and clear, but it is also important for what it said about other cases. One theme that Justice Breyer's majority opinion repeated is that extra antitrust deference is due to patent practices challenged under the Sherman Act when the practice is either expressly authorized by the Patent Act or is there "by fair implication."125 When that is not the case, antitrust should be given greater rein. The Actavis decision thus invites the courts to consider the permissible scope of anticompetitive patent licensing, including restraints that settle disputes and those resulting from ordinary business transactions. Of these, pay-for-delay settlements are an important but hardly the only part.

119. See supra notes 93-94 and accompanying text (discussing United States v. Gen. Elec. Co., 272 U.S. 476 (1926)).

120. 35 U.S.C. $§ 261$ (2006 \& Supp. V 2011) (permitting assignments or licenses covering "the whole or any specified part of the United States").

121. Actavis, 133 S. Ct. at 2240.

122. See supra notes $62-64$ and accompanying text.

123. 35 U.S.C. $\S 261$.

124. Id. § 271(d).

125. Actavis, 133 S. Ct. at 2233. 
